\title{
Accumulation of nitrogen and organic matter during primary succession of Leymus arenarius dunes on the volcanic island Surtsey, Iceland
}

\author{
G. Stefansdottir, A. L. Aradottir, and B. D. Sigurdsson \\ Agricultural University of Iceland, Hvanneyri, 311 Borgarnes, Iceland \\ Correspondence to: B. D. Sigurdsson (bjarni@lbhi.is)
}

Received: 6 March 2014 - Published in Biogeosciences Discuss.: 6 May 2014

Revised: 7 September 2014 - Accepted: 9 September 2014 - Published: 16 October 2014

\begin{abstract}
Initial soil development and enhanced nutrient retention are often important underlying environmental factors during primary succession. We quantified the accumulation rates of nitrogen $(\mathrm{N})$ and soil organic matter (SOM) in a 37year-long chronosequence of Leymus arenarius dunes on the pristine volcanic island Surtsey in order to illuminate the spatiotemporal patterns in their build-up. The Leymus dune area, volume and height grew exponentially over time. Aboveground plant biomass, cover or number of shoots per unit area did not change significantly with time, but root biomass accumulated with time, giving a root/shoot ratio of 19 . The dunes accumulated on average $6.6 \mathrm{~kg} \mathrm{Nha}^{-1}$ year $^{-1}$, which was 3.5 times more than is received annually by atmospheric deposition. The extensive root system of Leymus seems to effectively retain and accumulate a large part of the annual $\mathrm{N}$ deposition, not only deposition directly on the dunes but also from the adjacent unvegetated areas. SOM per unit area increased exponentially with dune age, but the accumulation of roots, aboveground biomass and SOM was more strongly linked to soil $\mathrm{N}$ than time: a $1 \mathrm{~g} \mathrm{~m}^{-2}$ increase in soil $\mathrm{N}$ led on average to a $6 \mathrm{~kg} \mathrm{C} \mathrm{m}^{-2}$ increase in biomass and SOM. The Leymus dunes, where most of the $\mathrm{N}$ has been accumulated, will therefore probably act as hot spots for further primary succession of flora and fauna on the tephra sands of Surtsey.
\end{abstract}

\section{Introduction}

Primary succession is the process of ecosystem development of barren surfaces with no previous developed soil or plant cover, such as new lava flows or areas left in front of retreating glaciers. Multiple environmental factors and ecosystem properties can act as thresholds in primary succession of such areas, not least a lack of nutrients, water and developed soil (del Moral and Grishin, 1999). Therefore the earliest colonists on volcanic tephra fields are often confined to specific microsites that offer some physical protection and enhanced nutrient resources from weathering, erosion or other nutrient inputs (Walker and del Moral, 2003). As some vegetation cover establishes on the pristine surfaces, organic matter $(\mathrm{OM})$ and soil organic nitrogen (SON) start to accumulate, which again improves the growing conditions for later successional species (Whittaker et al., 1989). Such "autogenic" (internal) factors are expected to determine the course of succession by traditional succession theory (Walker and del Moral, 2003), but "allogenic" (external) or stochastic factors (such as distance to potential colonists) also play an important role in some cases (del Moral et al., 2009; Marteinsdottir et al., 2010).

Pristine volcanic islands offer special conditions to study the processes of primary succession. New volcanic islands, or older islands completely disturbed by volcanic activity in historic times, are few; hence only a limited number of such studies exists, including, for example, Krakatau in Indonesia, which erupted in 1883 (cf. Whittaker et al., 1989), and most recently the Kasatochi Island in Alaska, which erupted in 2009 (Talbot et al., 2010). More work has been done on primary succession of lava flows from continental volcanos 
or where parts of volcanic islands have been disturbed by a new eruption (reviewed by Walker and del Moral, 2003).

The island of Surtsey emerged in an eruption that lasted from November 1963 to June 1967. Its undeveloped soil (tephra sand) contained only minute amounts of soil organic matter (SOM) and nitrogen (SON) in the beginning (Henriksson et al., 1987). Colonisation of vascular plants has been closely monitored on Surtsey since its emergence (Fridriksson, 1966, 1992; Magnússon and Magnússon, 2000; Magnússon et al., 2009, 2014). These studies show that the first plant community that successfully colonised the island consisted mainly of deep-rooted shore plants forming dense colonies of aboveground foliage (dunes or cushions) such as Leymus arenarius and Honckenya peploides, with large unvegetated areas in between.

The importance of spatial variation in early primary succession is receiving increasing attention (e.g. Cutler et al., 2008; del Moral et al., 2009; Cutler 2011; Garibotti et al., 2011). In patchy environments, positive feedback mechanisms can contribute to resource aggradation (cf. Rietkerk et al., 2002; Ehrenfeld et al., 2005), and we expect this to be the case for the Leymus dunes in Surtsey. Due to the careful monitoring of Surtsey's vegetation, the exact age of each Leymus dune is known, which presents an opportunity to study the effects of vegetation on the development of spatial variation in soil properties in the early stages of primary succession.

The main objective of this study was to assess the accumulation rates of SON and OM in Leymus arenarius dunes during primary succession on Surtsey. We sampled a 37-yearlong chronosequence of seven different-aged Leymus dunes, expecting to find a linear increase in the SON and SOC (soil organic carbon) with dune age that would indicate a gradual improvement of growing conditions. Furthermore we expected the Leymus to grow more vigorously and form denser aboveground canopy as it got older and accumulated more resources.

\section{Material and methods}

\subsection{Site description}

Surtsey (Fig. $1 ; 63.3^{\circ} \mathrm{N}, 20.6^{\circ} \mathrm{W}$ ) is the southernmost island of the Vestmannaeyjar archipelago, ca. $32 \mathrm{~km}$ off the south coast of Iceland. The local climate is cold-temperate oceanic, with an annual mean temperature of $5.0^{\circ} \mathrm{C}$ and mean annual precipitation of $1576 \mathrm{~mm}$ during the period 1965-2005, as recorded at the weather station on the island of Heimaey, $15 \mathrm{~km}$ to the northeast of Surtsey (Icelandic Met Office).

The first Leymus arenarius seedling was found on the island in 1966, before the eruption ceased (Fridriksson, 1966), but it did not establish. The first successful establishment of Leymus was in 1974, and that colony produced seeds for the first time in 1979 (Fridriksson, 1992). In 1983, the first successful seedling emergence of Leymus from local

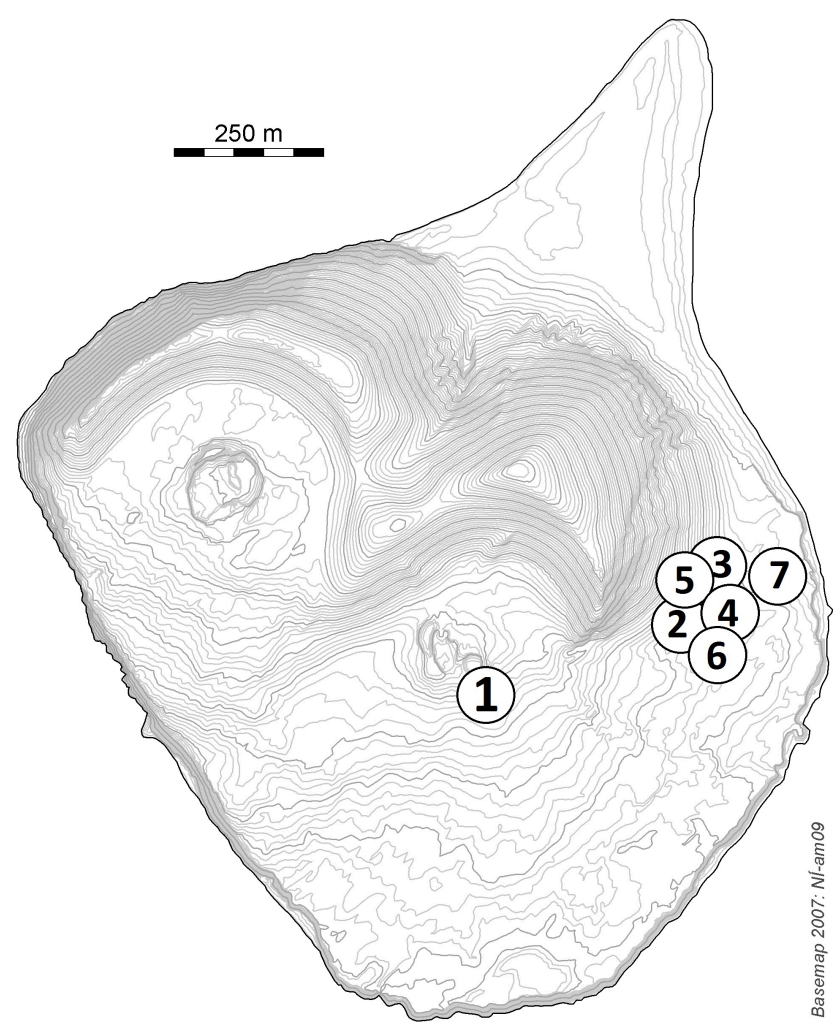

Figure 1. Location of the different-aged Leymus arenarius dunes selected on the southeast side of Surtsey, Iceland. See Table 1 for further information about different colonies.

seed sources was observed, and since then the species has spread over the whole island (Fridriksson, 1992; Magnússon et al., 2014). Leymus is currently, together with Honckenya, the most widespread plant species on the island. They form sparse communities on sandy areas (Magnússon and Magnússon, 2000), where the Leymus colonies accumulate characteristic sand dunes (cf. Greipsson and Davy, 1994). The vegetation cover of these tephra sands is generally below $20 \%$ (Magnússon and Magnússon, 2000) and was only $2.3 \%$ on the average in 2012 at the site of the present study (Magnússon et al., 2014). The tephra sands are also extremely nutrient-poor, with SON concentrations < $0.01 \%$ and SOC of $<0.05 \%$, with relatively high $\mathrm{pH}$ of 7.6 (Sigurdsson and Magnusson, 2010).

\subsection{Selection of a Leymus chronosequence}

The close monitoring of the establishment of all vegetation on Surtsey enabled the location of Leymus dunes of known age. Seven dunes of different age were selected on the southeast side of the island (Fig. 1). The two oldest dunes included the first successful Leymus colonisation and a dune from the first seeding episode in 1983 (Fridriksson, 1992), but younger dunes were all close to permanent study plots (nos. 13, 14, 15 and 21; Magnússon and Magnússon, 2000), and 
their establishment could be dated from annual photographs of them. The ages of the dunes at the time of sampling were $3,5,9,13,17,28$ and 37 years.

\subsection{Sampling protocol}

The dunes were mapped in July 2010 and 2011 by crossing two laterally levelled strings over the highest midpoint of each dune and measuring distance to the soil surface and soil depth (to $75 \mathrm{~cm}$ ) at $50 \mathrm{~cm}$ intervals along each string until the dune's edge was reached. Flowering stems of Leymus were counted on the whole dune. Three $30 \mathrm{~cm} \times 30 \mathrm{~cm}$ quadrats were randomly placed on the top of each dune, except on the four youngest ones, where only one quadrate could be fitted because of their smaller size. Additionally, quadrats were placed in the middle slope and at the expanding edge of the three oldest dunes, as well as $5 \mathrm{~m}$ outside them for comparison. In each quadrat, surface cover of all vascular plant species was recorded and the number of Leymus shoots counted. Furthermore, all aboveground biomass was harvested by cutting, and incremental soil samples of known volume were subsequently taken within the harvested quadrate. Continuous soil cores of known volume were taken to $5,10,20,30,45,60$ and $75 \mathrm{~cm}$ depth if bedrock was not reached earlier. All samples were sieved in situ through a $1 \mathrm{~cm}$ sieve and visible roots were separated and stored.

Biomass samples (roots and shoots) were dried at $105^{\circ} \mathrm{C}$ for 3-5 days and weighted for dry mass (DM). The roots were burned and their mass loss after ignition determined to correct for fine tephra sand that could not be cleaned from the roots. The soil samples were weighed after air drying until their DM was stable. They were then sieved through a $2 \mathrm{~mm}$ sieve, coarse fragments $(>2 \mathrm{~mm})$ weighed, and their volume measured by means of the water displacement method. All litter and fine roots found in the coarse fragments after sieving were weighed and added to the shoot and root samples, respectively. The fine soil fraction of all samples was ground for $2 \mathrm{~min}$ in a ball mill (MM200, Retsch, Haan, Germany) and their total SOC and SON concentrations analysed by means of dry combustion on a macro elemental analyser (model Vario MAX CN, Hanau, Germany). Soil samples were then dried at $105^{\circ} \mathrm{C}$ for $48 \mathrm{~h}$ and weighed again.

\subsection{Calculations and data analysis}

Aboveground dune volume was calculated for different depths of the four measured topographical transects, assuming that the shape of each height layer was a trapezoid and the topmost layer conical. The soil volume under the whole dune was also calculated for each depth interval, down to $75 \mathrm{~cm}$ depth where bedrock was not shallower. The drip line area of each dune was used as the outer boundary, i.e. not including the soil volume containing extending roots away from the dune's edge.
Soil $\mathrm{C}$ and $\mathrm{N}$ concentrations of each sample were corrected for difference in between air-dry DM and DM after drying at $105^{\circ} \mathrm{C}$. Sample bulk density $\left(\mathrm{BD}, \mathrm{g} \mathrm{cm}^{-3}\right)$ was calculated from fine-fraction DM and total sample volume after removal of the coarse-fraction volume. SOC and SON content per unit dune area $\left(\mathrm{g} \mathrm{m}^{-2}\right)$ and per measured dune mass $\left(\mathrm{kg} d u n e^{-1}\right)$ was calculated from the element concentrations, volume and $\mathrm{BD}$ of each layer.

Biomass C (shoots and roots) was calculated from measured DM. Shoot DM was multiplied by 0.40 , which is an unpublished factor based on measurements of Leymus shoot biomass and $\mathrm{C}$ by the Soil Conservation Service of Iceland (J. Thorsson, personal communication, 2012). The relatively low observed C fraction in Leymus plants is probably caused by the high dust content in the condition it grows in. Root $\mathrm{C}$ was calculated by multiplying the measured DM by 0.50 (Schiborra et al., 2009) after using the loss by ignition to adjust the DM to normal mineral content of $2.6 \%$ for grasses (Agricultural University of Iceland, unpublished data).

Differences in mean $\mathrm{C}$ stocks at different locations within the three oldest dunes was tested by post-ANOVA Fisher's least significant difference (LSD) tests in the SAS statistical program (SAS system 9.1, SAS Institute Inc., Cary, NC, USA). Age-dependent changes in $\mathrm{C}$ and SON stocks were tested by linear or exponential regression analysis in the SigmaPlot program (version 11.0, Systat Software Inc., San Jose, CA, USA).

\section{Results}

\subsection{Dune size and volume}

The surface area, height, aboveground volume and total volume to 30 and $75 \mathrm{~cm}$ soil depth of the Leymus dunes grew exponentially with age (Table 1 ), for the age span included in the present study (3-37 years). The soil depth outside the dunes was not significantly different, indicating that the starting conditions were comparable for all the dunes. To give an idea about relative size differences, the 10-, 20- and 30year-old dunes had ca. 45, 210 and 550\% larger surface area, were 70, 400 and $1350 \%$ taller and had 70, 405 and $1390 \%$ greater volume than the 5-year-old dunes, respectively.

\subsection{Soil and plant parameters per unit area}

Shoot density and surface cover of Leymus within each dune did not show a significant increase with age (Table 1); on average each dune had 56 shoots $\mathrm{m}^{-2}(\mathrm{SE} \pm 5)$ and $20 \%$ (SE $\pm 1 \%$ ) Leymus surface cover. The first flowering occurred in the 9-year-old dune, but density of flowering stems was not significantly related to dune age (Table 1). The Honckenya cover increased exponentially with dune age and reached $14 \%$ on the oldest dune (Table 1), but no other plant species were found on the dunes. Total aboveground biomass did not change significantly with age, when expressed per 
Table 1. Age (years) of the Leymus arenarius colonies/dunes, dune area $\left(\mathrm{m}^{2}\right)$, dune aboveground height $(H$; $\mathrm{cm})$, mean depth to bedrock under the colony $(D, \mathrm{~cm})$, aboveground dune volume $\left(V_{\mathrm{A}} ; \mathrm{m}^{3}\right)$, dune volume to $30 \mathrm{~cm}$ depth $\left(V_{30} ; \mathrm{m}^{3}\right)$, dune volume to $75 \mathrm{~cm}$ depth or less if it had shallower depth limit $\left(V_{75} ; \mathrm{m}^{3}\right)$, Leymus cover $\left(\mathrm{C}_{\mathrm{L}} ; \%\right)$, Honckenya cover $\left(\mathrm{C}_{\mathrm{H}} ; \%\right)$, shoot density $\left(S\right.$; no $\left.\mathrm{m}^{-2}\right)$, flowering stems $(F ;$ no $\left.\mathrm{m}^{-2}\right)$, aboveground biomass carbon $\left(B_{\mathrm{a}} ; \mathrm{g} \mathrm{C} \mathrm{m}^{-2}\right)$, root biomass carbon $\left(B_{\mathrm{r}} ; \mathrm{g} \mathrm{C} \mathrm{m}^{-2}\right)$, root / shoot ratio $(R / S)$, mean soil bulk density $(\mathrm{BD}$, $\mathrm{g} \mathrm{cm}^{-3}$ ), soil organic carbon (SOC; $\mathrm{g} \mathrm{C} \mathrm{m}^{-2}$ ), soil organic nitrogen (SON; $\mathrm{g} \mathrm{C} \mathrm{m}^{-2}$ ) and the $\mathrm{C} / \mathrm{N}$ ratio $(\mathrm{C} / \mathrm{N}$ ) of the dunes that were studied in Surtsey. The outcome of a linear or exponential regression analysis between age ( $x$ : years) and each variable; $P$ : ANOVA significance of the regression (ns: $>0.05 ; *: \leq 0.05 ; * *:<0.01 ; * * *:<0.001) ; R^{2}:$ coefficient of determination; $a$ : intercept of linear or exponential function; $b$ or $e$ : slope or exponent of linear or exponential function, respectively, depending on which function had higher $R^{2}$.

\begin{tabular}{|c|c|c|c|c|c|c|c|c|c|c|c|c|c|c|c|c|c|c|}
\hline \multirow[b]{2}{*}{ No. } & \multicolumn{7}{|c|}{ Dunes } & \multicolumn{7}{|c|}{ Plants } & \multicolumn{4}{|c|}{ Soil } \\
\hline & Age & Area & $H$ & $D$ & $V_{\mathrm{A}}$ & $V_{30}$ & $V_{75}$ & $\mathrm{C}_{\mathrm{L}}$ & $\mathrm{C}_{\mathrm{H}}$ & $S$ & $F$ & $B_{\mathrm{a}}$ & $B_{\mathrm{r}}$ & $R / S$ & BD & SOC & SON & $\mathrm{C} / \mathrm{N}$ \\
\hline 1 & 3 & 0.12 & 1 & 25 & 0.00 & 0.03 & 0.03 & 7 & 1 & 28 & 0 & 3.9 & 118.5 & 30.4 & 0.82 & 26.8 & 2.8 & 12.2 \\
\hline 2 & 5 & 0.07 & 1 & 54 & 0.01 & 0.02 & 0.05 & 8 & 2 & 28 & 0 & 2.1 & 264.5 & 24.2 & 1.29 & 48.9 & 3.8 & 13.8 \\
\hline 3 & 9 & 2.0 & 2 & $75^{*}$ & 0.01 & 0.6 & 1.5 & 30 & 5 & 119 & 0.50 & 36.4 & 462.4 & 12.7 & 1.24 & 98.7 & 6.6 & 16.2 \\
\hline 4 & 13 & 2.8 & 12 & 32 & 0.12 & 0.9 & 1.0 & 30 & 2 & 83 & 0.36 & 37.5 & 234.7 & 6.3 & 1.32 & 55.5 & 4.3 & 13.3 \\
\hline 5 & 17 & 11.6 & 27 & $75^{*}$ & 1.69 & 5.2 & 10.4 & 24 & 1 & 55 & 0.43 & 36.3 & 401.7 & 16.2 & 1.20 & 133.7 & 10.5 & 14.2 \\
\hline 6 & 28 & 211 & 45 & 70 & 39.0 & 102.4 & 184.2 & 18 & 5 & 31 & 0.13 & 33.1 & 531.7 & 23.6 & 1.09 & 333.6 & 20.4 & 12.0 \\
\hline 7 & 37 & 153.9 & 124 & 71 & 64.6 & 110.6 & 176.1 & 22 & 14 & 46 & 0.11 & 43.9 & 483.1 & 20.5 & 1.16 & 470.5 & 41.6 & 13.9 \\
\hline$P$ & & * & $* * *$ & ns & $* * *$ & ** & * & ns & $* *$ & ns & $\mathrm{ns}$ & ns & * & ns & ns & $* * *$ & $* * *$ & $\mathrm{~ns}$ \\
\hline$R^{2}$ & & 0.67 & 0.99 & 0.29 & 0.92 & 0.79 & 0.74 & 0.10 & 0.65 & 0.00 & 0.00 & 0.11 & 0.56 & 0.00 & 0.01 & 0.96 & 0.99 & 0.00 \\
\hline$a$ & & 11.89 & 2.34 & - & 1.26 & 4.72 & 9.13 & - & 0.69 & - & - & - & 210.4 & - & - & 44.1 & 2.48 & - \\
\hline$b$ & & - & - & - & - & - & - & - & - & - & - & - & 9.14 & - & - & - & - & - \\
\hline$e$ & & 0.075 & 0.107 & - & 0.108 & 0.088 & 0.084 & - & 0.080 & - & - & - & - & - & - & 0.065 & 0.076 & - \\
\hline
\end{tabular}

* No bedrock reached at maximum depth of $75 \mathrm{~cm}$.

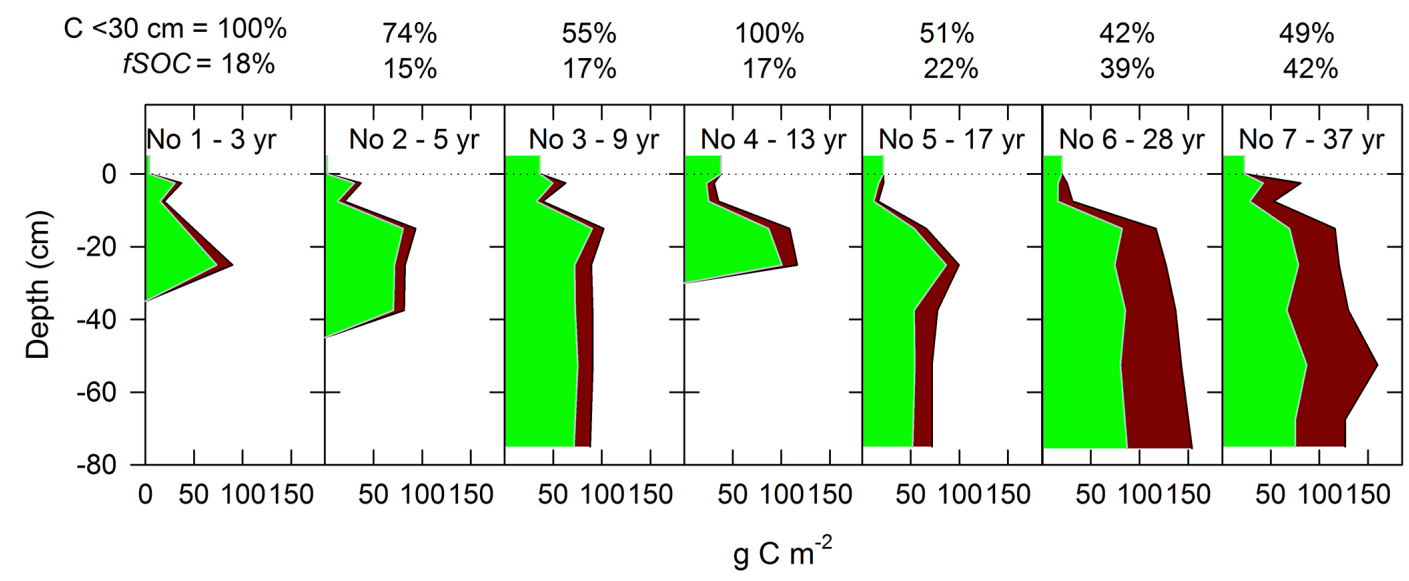

Figure 2. Distribution of aboveground (green, in carbon units, above the dotted line) and belowground plant biomass (green, below the dotted line) and soil organic carbon (brown) in a chronosequence of seven Leymus arenarius dunes on Surtsey ranging in age between 3 and 37 years. The profiles are all from the top of each dune. Above the diagram are the fractions of total ecosystem $\mathrm{C}$ stock found above $30 \mathrm{~cm}$ depth and the fraction of ecosystem $\mathrm{C}$ stock in soil organic matter ( $f$ SOC).

unit area, but root biomass increased significantly and linearly with age (Table 1). The root biomass per unit area increased on average by $9.1 \mathrm{~g} \mathrm{~m}^{-2}$ annually. The belowground root biomass in the Leymus dunes far exceeded their aboveground biomass (Fig. 2). The average root/shoot $(R / S)$ ratio was 19.1 ( $\mathrm{SE} \pm 1.2$ ), and did not change significantly with dune age, even if root biomass increased slightly (Table 1, Fig. 2).

The mean bulk density and $\mathrm{C} / \mathrm{N}$ ratio in the top $75 \mathrm{~cm}$ of soil, or down to the bedrock, in each dune were on average $1.16 \mathrm{~g} \mathrm{~cm}^{-3}(\mathrm{SE} \pm 0.02)$ and $13.7( \pm 0.2)$ and did not change significantly with age (Table 1). Mean SOC and SON concentrations did increase exponentially with age and were 17.6 and 14.9 times larger in the 37-year-old than in the 3year-old dune, respectively (Table 1). The actual concentrations were, however, always low, or on average 0.049 and $0.0037 \%$ for SOC and SON, respectively.

The fraction of SOC of total ecosystem C stock ( $f$ SOC) remained low, or between 15 and $20 \%$, until the dunes exceeded ca. 15 years; then the ratio increased and was $42 \%$ in the oldest dune (Fig. 2). The age-dependent increase in this fraction was significant $\left(P<0.002 ; R^{2}=0.88\right)$ and could be 
described by a positive linear function:

$f \mathrm{SOC}=8.4+0.9139 \times$ Age,

where age is in years. This function shows the first steps of soil development. It was also worth noting that both root biomass and SOC stocks were relatively stable with depth below the ca. $10 \mathrm{~cm}$ surface layer (Fig. 2), and where bedrock was not found at shallower depths. The maximum sampling depth was $75 \mathrm{~cm}$, but Fig. 2 indicates that the Leymus roots went deeper if soil depth allowed. Above- and belowground $\mathrm{C}$ stock above $30 \mathrm{~cm}$ soil depth was $67 \%$ (SE $\pm 3.5 \%$ ) of the total $\mathrm{C}$ stock down to $75 \mathrm{~cm}$, and this proportion did not change significantly with age of the dunes $(P=0.11)$.

\subsection{Spatial variability within the dunes}

The average $\mathrm{C}$ stocks in aboveground biomass, root biomass or SOC did not vary significantly among locations within dunes (Fig. 3). The top and middle areas of the dunes had significantly higher $\mathrm{C}$ stocks in all three compartments than the sparsely vegetated areas around them, which only contained a few small Honckenya plants, no Leymus shoots and very low aboveground biomass. The areas around the dunes had, however, 41 and $29 \%$, respectively, of the roots and SOC found in the dunes.

\subsection{Variables expressed per total dune area or volume}

The exponential increase in shoot biomass and root and SOC stocks with age, associated with larger surface area and total soil volume were even more apparent at a whole-dune scale (Fig. 4a). The annual SON accumulation rate was on average $6.6 \mathrm{~kg} \mathrm{Nha}^{-1}$ year $^{-1}(\mathrm{SE} \pm 0.9)$ and did not show significant age-dependent trend (Fig. 4b). A very strong linear relationship $\left(R^{2}>0.94 ; P<0.001\right)$ appeared between the amount of SON and the total shoot biomass $\left(\mathrm{C}_{\mathrm{S}}\right)$, total plant biomass $\left(\mathrm{C}_{\mathrm{P}}\right)$ and SOC stocks when expressed as a ln : ln scale (Fig. 4c), showing that the total ecosystem OM increased exponentially with time as more $\mathrm{N}$ became available. The linear $\ln : \ln \mathrm{SON}: \mathrm{C}$ functions were

$\ln \mathrm{C}_{\mathrm{S}}=0.6678+1.0705 \times \ln \mathrm{SON}$,

$\ln \mathrm{C}_{\mathrm{P}}=4.1541+0.8787 \times \ln \mathrm{SON}$,

$\ln \mathrm{SOC}=2.4846+1.0190 \times \ln \mathrm{SON}$.

When the total ecosystem $\mathrm{C}$ stock $\left(\mathrm{C}_{\text {tot }}, \mathrm{g} \mathrm{m}^{-2}\right)$ to $75 \mathrm{~cm}$ depth at the dune's edge (or down to bedrock if shallower than $75 \mathrm{~cm}$ ) in different dunes was compared to the total dune SON stock $\left(\mathrm{SON}_{\mathrm{tot}}, \mathrm{g} \mathrm{m}^{-2}\right)$, a significant linear relationship appeared $\left(P=0.03, R^{2}=0.57\right.$; data not shown):

$\mathrm{C}_{\text {tot }}=-22330+6039 \times \mathrm{N}_{\text {tot }}$.

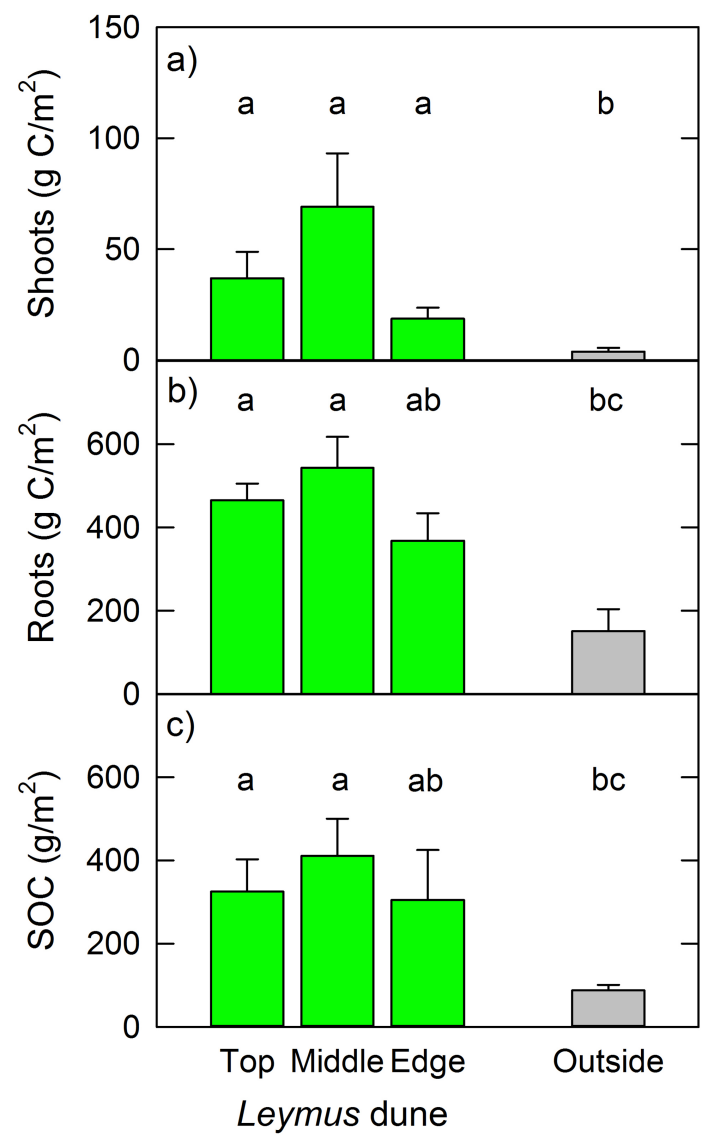

Figure 3. Mean shoot biomass (a), root biomass (b) and soil organic matter (c), all expressed in carbon units, in $75 \mathrm{~cm}$ deep cores taken in the centre, in the middle and at the expanding edge of three oldest Leymus dunes (nos. 5, 6 and 7). Additional cores were also taken to $75 \mathrm{~cm}$ depth ca. $5 \mathrm{~m}$ outside the dunes, for comparison. Vertical bars represent SE of $n=3-5$. Different letters above bars indicate significant differences $(P<0.05)$ found with post-ANOVA LSD tests.

In other words, there was $6.0 \mathrm{~kg} \mathrm{C} \mathrm{m}^{-2}$ accumulation in the dunes for every $1 \mathrm{~g} \mathrm{~m}^{-2}$ increase in the SON stock during the ca. 40 years after first establishment on the pristine volcanic island, giving an estimation of the average annual "nitrogen use efficiency" of the Leymus.

\section{Discussion}

\subsection{Dune size development}

The Leymus dunes are formed as eroding volcanic tephra sand is trapped by the vegetated patches. Their growth rate therefore depends both on the intercepting capacity of the Leymus plants and the intensity of the aeolian transport. All the dunes in our study except the youngest one were located within relatively small and homogeneous area (Fig. 1), where the aeolian transport can be assumed to be similar. The dune 

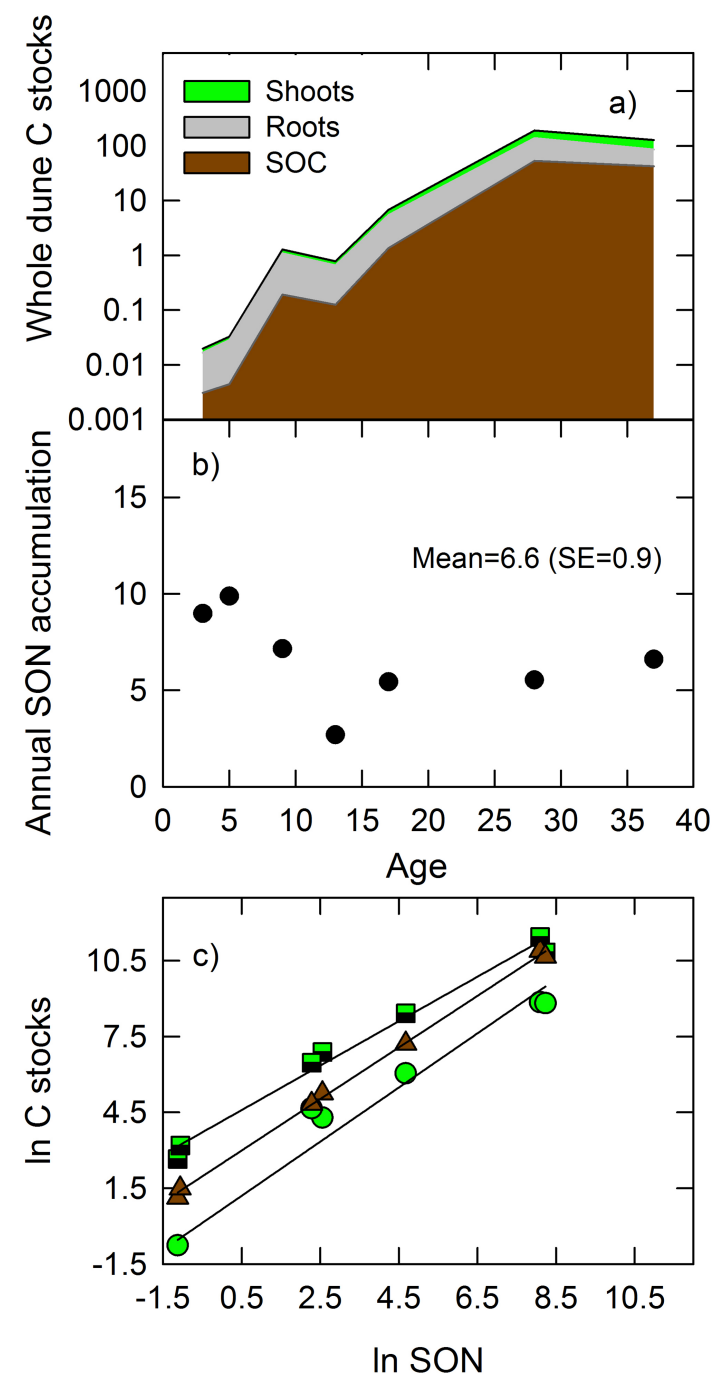

Figure 4. (a) Age-related changes in total Leymus dune $\mathrm{C}$ stocks $\left(\mathrm{kgC} \mathrm{dune}^{-1}\right.$ ) down to $75 \mathrm{~cm}$ soil depth at the dune's edge in shoots, roots and soil organic carbon (SOC). Note the logarithmic scale on the $y$ axis. (b) Mean annual accumulation of soil organic nitrogen (SON) in different-aged Leymus dunes. (c) The $\ln$ : ln relationship between total SON stocks in the different-aged dunes and total SOC stocks (circles), shoot biomass (triangles) and wholeplant biomass (squares), all expressed in $\mathrm{kgC} \mathrm{dune}^{-1}$. The lines indicate significant linear regressions.

height, surface area and volume increased exponentially with age. This is in contrast with previous studies on Leymus that assumed more-or-less constant growth rates and hence expressed their height increment with a single annual average (Greipsson and Davy, 1996).

As the dunes grew in size with age, their total element stocks calculated to the same soil depth outside the dunes increased. The observed increase in average element concentrations (\% DM) from the youngest to the oldest dune was 5.6- and 6.2-fold for SON and SOC, respectively, which clearly indicated that it was not simply an increasing size of the dunes which was causing the accumulation.

\subsection{Accumulation of SON}

The accumulation of SON has been slow on Surtsey, except in an area where seabirds formed a dense breeding colony after 1985 (Magnússon and Magnússon, 2000; Magnússon et al., 2009, 2014) and increased the ecosystem $\mathrm{N}$ accumulation with their droppings by ca. $50 \mathrm{~kg} \mathrm{~N} \mathrm{ha}^{-1}$ year $^{-1}$ (Leblans et al., 2014). Elsewhere on the island, where the sparse Leymus and Honckenya community is dominant, the average SON accumulation rate is ca. $1 \mathrm{~kg} \mathrm{Nha}^{-1}$ year $^{-1}$ (Leblans et al., 2014), which is about half of the expected atmospheric $\mathrm{N}$ deposition of areas in Iceland with annual precipitation of $1500 \mathrm{~mm}\left(1.8-2.0 \mathrm{~kg} \mathrm{~N} \mathrm{ha}^{-1}\right.$ year $^{-1}$; Gíslason et al., 1996; Sigurðsson et al., 2005).

The mean annual accumulation rate of SON within the dunes in our study was $6.6 \mathrm{~kg} \mathrm{~N} \mathrm{ha}^{-1}$ year $^{-1}$, or ca. 6 times higher than on average in the soil of same area on Surtsey (Leblans et al., 2014). There are several possible explanations for this difference: (i) translocation of $\mathrm{N}$ into the dunes from the unvegetated areas around with root transport, (ii) accumulation of $\mathrm{N}$ with wind-blown organic material that is trapped by the dunes, (iii) more $\mathrm{N}$ being transported by birds to dunes than to other areas, (v) free-living $\mathrm{N}$ fixation of soil bacteria within the dunes, or (vi) symbiotic $\mathrm{N}$ fixing with Leymus or Honckenya. The present experimental setup does not allow us to determine which individual pathways are responsible, but we argue that process (i) is the main contributor. The average Leymus surface cover of the permanent study plots in the same area (plots 13-16) in 2012 was only $0.9 \%$ and total plant cover was only $2.3 \%$ (Magnússon et al., 2014); in other words, $97.7 \%$ of the surface was unvegetated. Relatively large amounts of plant roots were, however, present in all soil samples taken among Leymus dunes in this area (Fig. 3b; Leblans et al., 2014). These roots are most likely to originate from the scattered Leymus dunes and can translocate nutrients and water into the dunes.

Of the other pathways, the aboveground translocation of $\mathrm{N}$ with wind-blown material and entrapment by dunes is probably also important. Such a pathway has been used to explain how Leymus and other dune-building species accumulate nutrients in barren and N-poor environments (Greipsson and Davy, 1994; Walker and del Moral, 2003). Some allochthonous nutrient inputs from birds cannot be ruled out either, but since breeding density on this part of the island is low (Petersen, 2009), it is probably mostly limited to overflying birds and therefore unlikely to be preferential towards the Leymus dunes. Free-living $\mathrm{N}$ fixing has been found to be absent or extremely low in the tephra sand in the present study area (Henriksson and Henriksson, 1974), while $\mathrm{N}$ fixing by the cyanobacterium Nostoc, associated with colonising mosses in other more sheltered areas of the island, was found to be substantial (Henriksson et al., 1987). 
No symbiotic $\mathrm{N}$ fixing was found in Honckenya growing in the study area in the 1970s (Henriksson and Henriksson, 1974) and only a low level of (free-living) $\mathrm{N}$ fixation was detected in soils from Leymus dunes (Henriksson and Henriksson and Rodgers, 1978). Symbiotic N fixation has, however, been found in coastal dunes of the closely related $L$. mollis in Oregon, USA (Dalton et al., 2004), and further investigation into whether symbiotic $\mathrm{N}$ fixing occurs in the Leymus in Surtsey is needed.

Whatever the source, the Leymus dunes have accumulated SON much faster than anticipated and that would have been estimated from the average atmospheric $\mathrm{N}$ deposition. If mainly derived with translocation from the unvegetated area around the dunes, then the Leymus is playing a very important role in $\mathrm{N}$ retention and build-up on the tephra sands of Surtsey. The Leymus in Surtsey is a classic example of a primary coloniser that acts as an environmental engineer that modifies its habitat with time and contributes to patchiness in resource availability (cf. Walker and del Moral, 2003; Ehrenfeld, 2005; del Moral et al., 2009). This is a typical example of reversed "Robin Hood" effect, where poor areas of the landscape are robbed of their scarce resources for the benefit of the richer patches in areas that are highly resource limited (cf. Ludwig and Tongway, 2000). On a new volcanic substrate like in Surtsey, the formation of such "hot spots" of resource availability may be essential for the subsequent formation of plant communities.

\subsection{Leymus growth}

It was worth noting that neither the Leymus surface cover, shoot density nor aboveground biomass per unit area changed significantly during the 37-year chronosequence, even if dune area grew exponentially with both age and SON stock. The Leymus apparently used the additional resources mainly to add new shoots at the dune's edge. The cover (density) of Leymus is, however, also dependent on the site's $\mathrm{N}$ availability, when compared across a wider $\mathrm{N}$-availability range than was done in the present study. On the permanent study plots on tephra sand within the seagull colony on Surtsey, where annual $\mathrm{N}$ accumulation was much higher (Leblans et al., 2014), the surface cover of Leymus was almost double, or $34 \%$ (Magnússon et al., 2014).

Leymus arenarius is a long-lived grass species (Greipsson and Davy, 1994) and there were no indications for any dieback within the oldest dunes, neither aboveground nor belowground. Such dieback may, however, occur when the dunes have reached a certain size (Greipsson and Davy, 1994). The earliest flowering of Leymus was seen in a 9-yearold dune, but a 5-year-old dune did not have any flowering stems. This fits well with the development of Leymus after the first successful colonisation on Surtsey, but it produced the first seeds 6 years after establishment (Fridriksson, 1992).

The $R / S$ ratio in the centre of the dunes did not show a significant trend with time. The $R / S$ ratio (average 19.1) was relatively high compared to vascular plants of tundra, grasslands and cold deserts that have on the average $R / S$ ratios of 4-5 (Mokany et al., 2006). Our calculation of $R / S$ ratio did not, however, take into consideration the Leymus roots that extended outside the dunes or below $75 \mathrm{~cm}$ depth. Leblans et al. (2014) estimated $R / S$ ratio of 45 for the general area in between dunes. The high $R / S$ ratio of Leymus is probably the key reason for its ability to colonise and survive in the nutrient-poor and unstable tephra sands of Surtsey. This is also in good accordance with the observation of Chapin (1993), who claimed that adaptations for large nutrient acquisition and retention were generally key factors for the success of early colonisers in primary succession.

\subsection{OM accumulation}

Carbon fixation (net photosynthesis) by the early colonisers, organic matter production, litter fall and the microbial breakdown of litter and humus drive the accumulation of SOM, without which soil will not develop during primary succession (del Moral and Grishin, 1999; Walker and del Moral, 2003). After the first 5 years, aboveground biomass per unit dune area remained more or less constant, and the standing aboveground biomass was similar to that reported in a 39 -year chronosequence on previously eroded revegetation areas in Iceland seeded by Leymus arenarius and initially fertilised with about $100 \mathrm{~kg} \mathrm{Nha}^{-1}$ (Aradóttir et al., 2000). Root biomass and $R / S$ ratio were, however, much higher in the present study than were reported for the fertilised Leymus treatments. This was partly because the sampling depth was limited to $30 \mathrm{~cm}$ in Aradóttir et al. (2000), but could also be partly caused by difference in fertility as $\mathrm{N}$ availability is known to strongly affect $R / S$ ratios in plants (Marschner et al., 1996). SOC stocks of the dunes on Surtsey increased exponentially with age and the $f$ SOC ratio (ratio of SOC to total ecosystem C stock) increased linearly (Eq. 1). Still, after 37 years the SOC stock in the top $30 \mathrm{~cm}$ was only ca. $15 \%$ of total living biomass (including roots down to $30 \mathrm{~cm}$ ), but ca. 7 times higher than aboveground biomass per unit dune area. In the Aradóttir et al. (2000) chronosequence on the mainland, the SOC ratio to aboveground biomass was much higher after 39 years (ca. 22 times higher). The reasons for this could be much faster root turnover in Leymus on the mainland, which is a known response to fertilisation of other ecosystems (Leppälammi-Kujansuu et al., 2014). It cannot, however, be ruled out that some SOC had remained since before the erosion took place in the mainland chronosequences, which would also translate into similar differences.

It should be noted when $\mathrm{C}$ stocks were scaled to wholedune level and down to $75 \mathrm{~cm}$ depth below the dunes (where depth to bedrock allowed) as in Table 1 and Fig. 4, the fraction of SOC to living biomass changed, since the surface area scaled less than volume.

The strong relationships between SON and both biomass and SOC stocks found in the present study, and that those 
relationships were a stronger predictor of $\mathrm{OM}$ accumulation than time (age) since colonisation, suggest strongly that $\mathrm{N}$ availability plays a major role in the primary succession on the tephra sands on Surtsey. This further supports such indications found for vascular plant cover and species composition in different habitats on the island (Magnússon and Magnússon, 2000; Magnússon et al., 2009, 2014; del Moral and Magnússon, 2014) and for process rates, such as ecosystem respiration (Sigurdsson and Magnusson, 2010). Therefore the "nitrogen use efficiency" for ecosystem C stocks estimated by Eq. (5) and the SON relationships for individual C components reported in Eqs. (2)-(4) might be used for modelling the primary succession of Leymus arenarius in similar habitats. An interesting extension of the present work could also be to further study the importance of symbiotic mycorrhizal fungi in the $\mathrm{N}$ scavenging of the Leymus roots.

\section{Conclusions}

The history of annually monitoring colonisation, growth and mortality of individual plants on Surtsey since it emergence in 1963 offered a special opportunity to use a chronosequence approach to study how autogenic (internal) factors develop after colonisation of a keystone species in the primary succession. Leymus arenarius, with its high $R / S$ ratios, is probably a key player in $\mathrm{N}$ retention and soil development on the tephra sands of the island. The high correlation between SON and OM stocks indicated that the rate of primary succession was more strongly controlled by the amount of available $\mathrm{N}$ than time since colonisation per se. The Leymus dunes, where $\mathrm{N}$ has been accumulated, will therefore probably act as hot spots for further primary succession of flora and fauna within this area of Surtsey - at least if new sources of $\mathrm{N}$ do not appear, such as establishment of new seabird colonies or introduction of new symbiotic $\mathrm{N}$-fixing plant species.

Acknowledgements. The Surtsey Research Society, Icelandic Institute of Natural History and the Icelandic Coastguard provided logistical support for the present study. Anette Th. Meier made the elevation map of the island. Framleiðnisjóður landbúnaðarins (the Agricultural Productivity Fund) supported the work of the first author. Borgthor Magnússon is acknowledged for inspiring the start of this study and giving many constructive comments. This work also contributes to the FSC-Sink, CAR-ES and ClimMani projects.

Edited by: J.-A. Subke

\section{References}

Aradóttir, Á. L., Svavarsdóttir, K., Jónsson, P. H., and Guðbergsson, G.: Carbon accumulation in vegetation and soils by reclamation of degraded areas, Icelandic Agric. Sci., 13, 99-113, 2000.
Chapin III, F. S.: Physiological controls over plant establishment in primary succession, in: Primary Succession on Land, edited by: Miles, J., and Walton, D. W. H., Special publications of the British Ecological Society, 12, Blackwell Scientific Publications, London, UK, 1993.

Cutler, N.: Vegetation-environment interactions in a sub-arctic primary succession, Polar Biol., 34, 693-706, doi:10.1007/s00300010-0925-6, 2011.

Cutler, N. A., Belyea, L. R., and Dugmore, A. J.: The spatiotemporal dynamics of a primary succession, J. Ecol., 96, 231-246, doi:10.1111/j.1365-2745.2007.01344.x, 2008.

Dalton, D. A., Kramer, S., Azios, N., Fusaro, S., Cahill, E., and Kennedy, C.: Endophytic nitrogen fixation in dune grasses (Ammophila arenaria and Elymus mollis) from Oregon, FEMS Microbiol. Ecol., 49, 469-479, doi:10.1016/j.femsec.2004.04.010, 2004.

del Moral, R. and Grishin, S. Y.: Volcanic disturbances and ecosystem recovery, in: Ecosystems of Disturbed Ground, edited by: Walker, L. R., Elsevier Science B.V., Amsterdam, the Netherlands, 1999.

del Moral, R. and Magnússon, B.: Surtsey and Mount St. Helens: a comparison of early succession rates, Biogeosciences, 11, 20992111, doi:10.5194/bg-11-2099-2014, 2014.

del Moral, R., Sandler, J. E., and Muerdter, C. P.: Spatial factors affecting primary succession on the Muddy River Lahar, Mount St. Helens, Washington, Plant Ecol., 202, 177-190, doi:10.1007/s11258-008-9506-y, 2009.

Ehrenfeld, J. G., Ravit, B., and Elgersma, K.: Feedback in the plant-soil system, Ann. Rev. Env. Resour., 30, 75-115, doi:10.1146/annurev.energy.30.050504.144212, 2005.

Fridriksson, S.: The pioneer species of vascular plants in Surtsey, Cakile edentula, Surtsey Res. Prog. Rep., 2, 63-65, 1966.

Fridriksson, S.: Vascular plants on Surtsey 1981-1990, Surtsey Res. Prog. Rep., 10, 17-30, 1992.

Garibotti, I. A., Pissolito, C. I., and Villalba, R.: Spatiotemporal pattern of primary succession in relation to meso-topographic gradients on recently deglaciated terrains in the Patagonian Andes, Arct. Antarct. Alp. Res., 43, 555-567, doi:10.1657/1938-424643.4.555, 2011.

Gíslason, S. R., Arnórsson, S., and Ármannsson, H.: Chemical weathering of basalt in southwest Iceland: effects of runoff, age of rocks and vegetative/glacial cover, Am. J. Sci., 296, 837-907, 1996.

Greipsson, S. and Davy, A. J.: Leymus arenarius. Characteristics and uses of a dune-bulding grass, Icelandic Agric. Sci., 8, 41-50, 1994.

Greipsson, S. and Davy, A. J.: Sand accretion and salinity as constraints on the establishment of Leymus arenarius for land reclamation in Iceland, Ann. Bot., 78, 611-618, doi:10.1006/anbo.1996.0168, 1996.

Henriksson, L. E. and Henriksson, E.: Studies in the nitrogen cycle of Surtsey in 1972, Surtsey Res. Prog. Rep., 7, 36-44, 1974.

Henriksson, L. E. and Rodgers, G. A.: Further studies in the nitrogen cycle of Surtsey, 1974-1976, Surtsey Res. Prog. Rep., 8, 30-40, 1978.

Henriksson, E., Henriksson, L. E., Norrman, J. O., and Nyman, P. O.: Biological dinitrogen fixation (acetylene reduction) exhibited by blue-green algae (cyanobacteria) in association with mosses gathered on Surtsey, Iceland, Arct. Alp. Res., 19, 432-436, 1987. 
Leblans, N. I. W., Sigurdsson, B. D., Roefs, P., Thuys, R., Magnússon, B., and Janssens, I. A.: Effects of seabird nitrogen input on biomass and carbon accumulation after 50 years of primary succession on a young volcanic island, Surtsey, Biogeosciences Discuss., 11, 6269-6302, doi:10.5194/bgd-11-6269-2014, 2014.

Leppälammi-Kujansuu, J., Salemaa, M., Kleja, D., Linder, S., and Helmisaari, H.-S.: Fine root turnover and litter production of Norway spruce in a long-term temperature and nutrient manipulation experiment, Plant Soil, 374, 73-88, doi:10.1007/s11104013-1853-3, 2014.

Ludwig, J. A. and Tongway, D. J.: Viewing rangelands as landscape systems, in: Rangeland Desertification, edited by: Arnalds, O. and Archer, S., Kluwer Academic Publishers, Dordrecht, the Netherlands, 39-52, 2000.

Magnússon, B. and Magnússon, S. H.: Vegetation succession on Surtsey during 1990-1998 under the influence of breeding gulls, Surtsey Res. Prog. Rep., 11, 9-20, 2000.

Magnússon, B., Magnússon, S. H., and Fridriksson, S.: Development in plant colonization and succession on Surtsey during 1999-2008, Surtsey Res., 12, 57-76, 2009.

Magnússon, B., Magnússon, S. H., Ólafsson, E., and Sigurdsson, B. D.: Plant colonization, succession and ecosystem development on Surtsey with reference to neighbouring islands, Biogeosciences, 11, 5521-5537, doi:10.5194/bg-11-5521-2014, 2014.

Marteinsdottir, B., Svavarsdottir, K., and Thorhallsdottir, T. E.: Development of vegetation patterns in early primary succession, $\mathrm{J}$. Veg. Sci., 21, 531-540, doi:10.1111/j.1654-1103.2009.01161.x, 2010.

Marschner, H., Kirkby, E. A., and Cakmak, I.: Effect of mineral nutritional status on shoot-root partitioning of photoassimilates and cycling of mineral nutrients, J. Exp. Bot., 47, 1255-1263, doi:10.1093/jxb/47.Special_Issue.1255, 1996.
Mokany, K., Raison, R. J., and Prokushkin, A. S.: Critical analysis of root: shoot ratios in terrestrial biomes, Glob. Change Biol., 12, 84-96, doi:10.1111/j.1365-2486.2005.001043.x, 2006.

Petersen, A.: Formation of a bird community on a new island, Surtsey, Iceland, Surtsey Res., 12, 133-148, 2009.

Rietkerk, M., Boerlijst, M. C., van Langevelde, F., HilleRisLambers, R., van de Koppel, J., Kumar, L., Prins, H. H. T., and de Roos, A. M.: Self-organization of vegetation in arid ecosystems, Am. Nat., 160, 524-530, doi:10.1086/342078, 2002.

Schiborra, A., Gierus, M., Wan, H. W., Bai, Y. F., and Taube, F.: Short-term responses of a Stipa grandis/Leymus chinensis community to frequent defoliation in the semi-arid grasslands of Inner Mongolia, China, Agric. Ecosyst. Environ., 132, 82-90, 2009.

Sigurðsson, A. S., Magnússon, S. H., Thorlacius, J. M., Hjartarson, H., Jónsson, P., Sigurðsson, B. D., Magnússon, B., and Óskarsson, H.: Integrated monitoring at Litla-Skard, Iceland. Project overview 1996-2004, Umhverfisstofnun, Reykjavik, Iceland, 65, 2005.

Sigurdsson, B. D. and Magnusson, B.: Effects of seagulls on ecosystem respiration, soil nitrogen and vegetation cover on a pristine volcanic island, Surtsey, Iceland, Biogeosciences, 7, 883-891, doi:10.5194/bg-7-883-2010, 2010.

Talbot, S. S., Talbot S. L., and Walker L. R.: Post-eruption legacy effects and their implications for long-term recovery of the vegetation on Kasatochi Island, Alaska. Arct. Antarct. Alp. Res., 42, 285-296, doi:10.1657/1938-4246-42.3.285, 2010.

Walker, L. R. and del Moral, R.: Primary succession and ecosystem rehabilitation, Cambridge University Press, UK, 2003.

Whittaker, R. J., Bush, M. B., and Richards, K.: Plant recolonization and vegetation succession on the Krakatau Islands, Indonesia, Ecol. Monogr., 59, 59-123, doi:10.2307/2937282, 1989. 